\title{
Student teachers' perspectives on their readiness towards teaching practice: A case study in a Malaysian university
}

\author{
Ikhsan Othman, Abdul Talib Mohammed Hashim, Azli Ariffin, Zaini Abdullah, Abu Bakar Yusof. \\ Sultan Idris Education University, Tanjong Malim, Perak, Malaysia \\ Corresponding author: ikhsan@fpm.upsi.edu.my
}

DOI: https://doi.org/10.37134/jrpptte.vol9.no1.2.2019

Received: 15 April 2019; Accepted: 05 May 2019; Published: 17 June 2019

\begin{abstract}
This paper discusses part of the findings in a case study conducted to student teachers who were in teacher education programme in a selected university. The discussion focuses on the findings of interviews done to the students regarding with their readiness for their teaching practice or teaching practice at schools where there were placed. Open ended interviews were done to randomly ten students who had gone to the schools for their social visit before they go for their teaching practice. Audio data were collected from the participants of the interviews. The data were analysed and categorised thematically. There were main themes of the readiness that emerged from the analysis include social readiness, psychological readiness, general pedagogical knowledge readiness, pedagogical content knowledge readiness and basic skills readiness. The findings show that the student teachers admitted confidently that they were ready socially and psychologically for their teaching practice. They were also had readiness on the aspects of general pedagogical knowledge, pedagogical content knowledge and basics skills that will be required for the performing of the teaching practice. These findings might have connection with why most of the students scored higher achievement grade in teaching practice. Therefore further study might also be conducted to acquire clearer picture to be noted about it.
\end{abstract}

Keywords: Readiness, teaching practice.

\section{INTRODUCTION}

The basic task of teacher education program is to produce higher quality of beginning teachers who ${ }^{1}$ can face challenges and do well in their job and bear responsibility as teachers. Findings by Goh, Wong, Rosma \& Chia (2012) showed that beginning teachers, that is within one to three years service, had gain the conception of competency in the ability to manage classroom and students' behaviour; have strong knowledge of the subject content; able to reach out for assistance and support; understanding the students they teach; and possessing the values of professionalism. These are really challenging. By

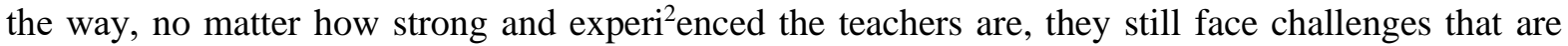
continously changing upon the time in their career (Eftah \& Izazol, 2014; Sazwani, Noor Shah \& Sazelli, 2011). Findings of previous studies also show that the early years of beginning teachers is a difficult period to be passed through, where they have to struggle much in their career as a teacher (Mohd Hasani \& Ulaganathan, 2005; Nabilah \& Nurshamsida, 2011; Mohammed Sani \& Zuraidah, 2002). ${ }^{3}$

As teachers, they should have very firm criterions relevance with their task and responsibility (Goh \& Wong, 2015; Goh \& Wong, 2014). Consequently it requires begining teachers to constantly

* Corresponding author: Email: ikhsan@fpm.upsi.edu.my 
equip themselves with the necessary knowledge, skills, values and competencies to face the situation. In Malaysia, educating new teachers through teacher education program is in line with the aspiration of Philosophy of Teacher Education (PTE). The PTE is as stated below.

"Teacher who is noble in character, progressive and scientific in outlook, committed to uphold the aspiration of the nation, and cherishes the national cultural heritage, ensures the development of individual and the preservation of a united, democratic, progressive and discipline society."

(Malaysia Ministry of Education, 1982)

Obviously teachers in Malaysia have the responsibility in the development of individuals and the preservation of a united, democratic, progressive and discipline society. Only the quality teachers can facilitate the future human capital to gain knowledge and skills as well as sculpting attitude and fostering positive values. Therefore teacher education institutions that produce begining teachers, must play the significant roles in the development of quality teachers as the institutions are given full responsibilities by the government to produce the prospective teachers.

In teacher education program, something were designed in order for the student teachers to acquire the best experiences, skills and confidence to be able to start their career as beginning or novice teachers which will later become experienced or quality teachers as required (Goh, Wong, Rosma \& Chia (2012). Therefore student teachers must passed through certain professional education courses conducted by teacher education institutions for their professional development. Basically the courses include theoretical courses as well as practical courses or teaching practice.

Teacher education program requires careful blending of both theory and practice in its curriculum. With the lack of either theoretical or practical part, the program will be insufficient and aimless. The blending of theory and practice will brings the student teachers to both reflective as well as active dimension in classroom. There is a strong relationship between students teacher achievement in theoretical courses and the practical part (Furlong, 2000). Therefore it is important to include teaching practice course in the program. In the university where this study was done, the teacher education program consist of courses namely Professional Education Courses, University Courses, Specialties Major, Minor Courses, Co-curriculum Courses that focus on theory; and Teaching Practice that focus on practical (Ikhsan \& Norila, 2016). Teaching practice is one of the main component of courses in teacher education program that generally practiced after student teacher had passed through most of the theoretical courses in the program.

Commonly there are two models of teacher education namely consecutive model and simultaneous model (Furlong, 2000). In consecutive model, student teachers first obtain content knowledge of subject specialization followed by additional courses that focus on knowledge, skills and values in teaching. While in concurrent model, student teachers study simultaneously both academic subject (content knowledge) and relevant courses which lead to teaching ways of the subject. In both models that is whether consecutive model or concurrent model, student teachers need to undergo teaching practice or practicum. Anyway we can find that different teacher education institution will have their different way of implementing the teaching practice; which shouldn't be an issue.

In the university where this study was done, teacher education program consist six components of courses namely Professional Education Courses (PEC), University Courses (UC), Specialties Major (SM) and Minor Courses (MC), Co-curriculum Courses and Practicum (Ikhsan Othman, Norila Md Salleh, 2016). Every student in the program must passed through the courses in order to qualify them to be a teacher. Teaching practice takes a period of 16 weeks ( 8 credit hour) where student teachers were placed in a selected school in the seventh semester. Consecutively, there is a semester (the 8th semester) where the students will come back to lecture halls for the reflection of the teaching practice. During teaching practice, student teachers do not only learn to practice what they have learnt in their lecturer halls theoretically such as courses of their specialized subject or content knowledge; general pedagogical knowledge; and pedagogical content knowledge of the subject, but they also have to adapt themselves to a real setting and natural school-working environment. 


\section{Background of Study}

This paper discusses students' perspectives on their readiness for practical courses or teaching practice based on interviews done to them. The discussion is limited to only part of the findings of the whole study done to a cohort of 1,888 students teacher who followed teacher education program in a selected university. The study was conducted based on issues regarding with teaching practice amongst student teachers. During teaching practice, a study by Melor et al. (2010) found that most of student teachers were weak at communication skills with their supervisors which were then triggered other weaknesses. The study also found that the main challenges that the student teachers faced were the cultural differences that further brought to cultural shock problem.

Findings from a study by Zailani (2012) indicate that student teachers faced various challenges ranging from the very basic interpersonal to a complex pedagogical issues during performing their teaching practice. A study by Ikhsan \& Norila (2016) also showed that there was a weak significant correlation between students' achievement in professional education course which is more theoretical and the students' achievement in teaching practice which is more to practical and real setting. From the findings, it possibly implies that student teachers might have not ready for their teaching practice; or it seems like there are many issues in conjunction with student teachers' readiness for their teaching practice. Although such findings are based on studies passed years before; as time goes by such findings might become different but it is in doubts if the scenario is continuing. Therefore this study was meant to review such situation.

\section{RESEARCH OBJECTIVE}

The related objectives of study as focus for this discussion is to explore student teachers readiness towards undergoing teaching practice.

\section{Research Question}

The related research question of study as focus for this discussion is as stipulated below.

a) What are the basic themes of students' perception regarding with their readiness for teaching practice?

b) Do student teachers have their rediness to undergo teaching practice at the end of their studies in teacher education program?

\section{METHODOLOGY}

In the overall study as a whole, quantitative and qualitative data were gathered and analysed. However in this article the discussion is limited to student teachers' perspective on their readiness just before or specifically within a week before they go for their teaching practice. It was a survey conducted with open ended interviews to randomly 10 students who just finished their sixth semester of their teacher education program and who are about to go for their teaching practice in the following semester, that is their seventh semester. The interviews were done after the students completed their sixth semester final examination by a team of trained interviewers with the used of a precise interview protocol designed suitably for this study.

Audio data was recorded with audio recorder during the interview sessions. The data collected from the interviews were then transcribed. The interview transcripts were read several times to find common themes that emerged. It was then grouped thematically for data analysis (Boeije, 2010, Creswell, 2007). According to Boeije (2010), "qualitative data analysis is the segmenting of data into relevant categories and the naming of this categories with codes while simultaneously generating the categories form data." The data was analysed to answer the research question as mentioned above. 


\section{FINDINGS}

There were main categories or themes regarding with students' perception on their readiness for teaching practice that emerged based on data analysis. Anyway only five themes are presented and discussed in this paper namely students' social readiness; students' psychological readiness; students' content knowledge readiness; students' pedagogical content knowledge readiness and students' basic skills readiness. It is put to a digramatic form as Figure 1.

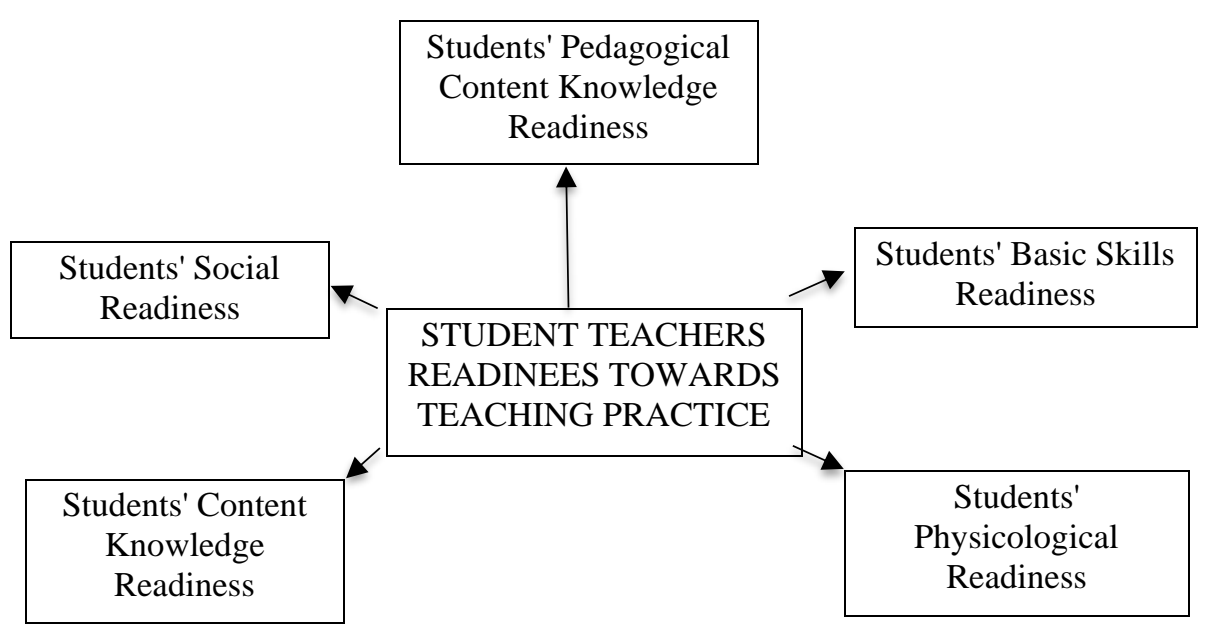

Figure 1 Five Themes of Student Teachers' Readiness Toward Teaching Practice

\section{- $\quad$ Students' Social Readiness}

Students' social readiness in this study refers to readiness on how the student teachers interact and socialize with personals who were involved during their stay at the school for their teaching practice. Such personals are teachers, pupils, non-academic staffs, parents and the surrounding communities. This happened starting from their first visit or called social visit to the school for the preparation of their stay for teaching practice. Besides that, social aspect also include their interaction and communication with their lecturer, school principal and senior teacher who will become their supervisors for their teaching practice. It also covers the aspect of student teachers' communication and interaction with school pupils.

There is a course in PEC, that covers more on the topics of sociology in education. This course exposes the student teachers with the related knowledge, skills and values on the aspect of sociology. Psychology of education is another courses in PEC that may support student in this matter. With these basic knowledge and skills, it was expected that the student teachers were well prepared for their teaching practice.

Based on interviews for these aspects, finding shows that student teachers admitted that they were ready or well prepared for their teaching practice. They have their readiness regarding with the school and with all of the mentioned parties that they will get involved during the stay for their teaching practice. There were many words from the participants recorded for that in the interviews and below are among their words.

"I went to the school and I really like the school as it is so attaractive and conducive for me to practice what ever I've learnt so far from my lecturer in lecture hall" (TT08).

"Teachers in the school were so welcoming and friendly. They providedme with tips that 
are necessary for the interaction with school pupils, other teachers and non-academic staffs" (TT01).

"There were teachers which offered their help for the search of house for accomodation as well as transport during my stay for teaching practice which is nearby to the school" (TT06).

There are reasons that attracted the student teachers for the readiness. The students experienced the conduciveness of the school when they first went to the school for their social visit before teaching practice. Other than that, the attitude of the teachers at the school, where the teachers are mostly welcoming and helping. When the participants of the study were further asked whether their readiness is also because of the exposure by their lecturers in sociology of education based courses in their lecture hall; such participants were not denying the reason.

\section{- $\quad$ Students' Psychological Readiness}

Students' psychological readiness in this study refers on their thinking, their confidence as well as their feeling upon performing teaching practice. These aspects will effect much on their behaviour as well as their physical outlook as trainee teachers. From this point of view, the participants in the interviews expressed their psychological readiness for their teaching practice. The following statements were among those admitted by participants in the interviews.

"I'm so confident to go for my teaching practice as I've waited the opportunity for so long. Now I'll go to school as a teacher although it's just a practice (Teaching Practice)" (TT07).

"I feel so happy to go for my teaching practice; also I feel I've the strength to interact face to face with pupils at the school and face whatever challenges that will emerge there." (TT02).

"I will go to the school as teacher trainee during my teaching practice. I realise that I will face many challenges. Anyway I feel I'm confident for that" (TT06).

The participants in the interviews were also asked on the reason why they have that kind level of confidence. Most of them responded that the knowledge and understanding on psychology given in lecture hall by lectures were so helpful and very constructive.

\section{- $\quad$ Students' Content Knowledge Readiness}

Generally the teaching practice was programmed for students in the seventh semester after the students have learnt almost all courses of teacher education program especially specialist major courses and also minor courses that the student teachers are specialised in. The courses are basically related with the subjects that the student teachers are going to teach during their teaching practice as posted as teachers. In the preparation, student teachers were exposed with content knowledge of the subject in lecture hall through various courses theoretically and practically.

From the interviews done in this study, the participants admitted that they were ready to teach their pupils knowledge of the subject during the teaching practice. The following statements were among those mentioned by participants in the interviews.

"...most probably I'll be given Form 2 subjects to teach. Form 2 level of knowledge generally very easy. Actually I always keep in touch with the subject by browsing internet to check and make sure the latest syllabus of the subject published by MOE (Ministry of Education)." (TT09). 
". . . of course my memory on the content of the subject that I had learnt when I was a school student years before will has its great contribution for my confidence to go for my teaching practice." (TT05).

But it was also undeniably that exposure during lecture hours in university contributed most of the knowledge besides the knowledge that they have learnt during their school time years before.

"My lecturers gave me more new knowledge as well as skills of the subject that I'm going to teach at school. That helped me so much and that made me so confident with my subject knowledge." (TT03).

"I love the subject that I am now majoring since my school time. It is advantage for me. More or less it contributes to my confidence in teaching the subject when I perform my teaching practice." (TT03).

\section{- $\quad$ Students' Pedagogical Content Knowledge Readiness}

Other than content knowledge, student teachers are also exposed with pedagogical content knowledge theoretically in lecture halls as well practically in micro teaching labs with the hope that the student teachers will get prepared before they go for their teaching practice. Shulman in1987 believed that student teachers must be exposed and master with pedagogical content knowledge (PCK) of their majoring subject before they can go for teaching (Nagendralingan, 2002). It was well done and given to the students by lectures. The following statements were recorded from those participants in the interviews.

"I believe that I can implement what I've studied in pedagodical courses from my lectures and acquired the skills from my micro and macro teaching in labs" (TTO1).

"There are two types of pedagogical knowledge. One is general pedagogy while the other is pedagogy for the certain subject. In this case I was thought with both type of knowledge. Therefore I feel I'm ready to implement that knowledge for my teaching practice" (TT10).

"As had been exposed by lectures regarding with pedagogical content knowledge, I feel of no reistance to implement the knowledge. It is something advance from what I have seen especially as what I have seen when I was a school student" (TT04).

From interviews done in this study; it can be summarised that the participants admitted to have the readiness of pedagogical content knowledge of the subject that they are majoring in.

\section{- $\quad$ Students' Basic Skills Readiness}

There are also skills exposed to the participants of this study while they are following teacher education program. The basic skills include teaching skills; classroom management skills; communication skills; student teacher interaction skills; ICT skills; soft skills and so forth. Those skills are important as their basis to become a good teacher. After six semesters they were exposed with those skills, student teachers felt that they were confident to apply what they have learnt for their teaching practice. The following statements were among those collected from the participants in the interviews.

"It's good to acquire basic skills necessary in teaching profession; and now I'm ready to try out those skills in school real environment during my teaching practice." (TT03). 
"The most and very challenging is interaction skills between pupils and me as a teacher trainee. Nowadays pupils are more aggressive and out spoken. Teachers need to be patient. I believe I manage to do it." (TT09).

"Although I'm well prepared with my ICT skills, I'm not sure wether I can develop those skills to among pupils because the infranstructure in certain schools is of major problems. Any way I for see what I can do ... " (TTO2).

Besides that, the interviewed participants also admitted that overall exposure given to them in or out of lecture hall in teacher education program at the university was really significant in developing and nourishing their soft skills that undeniably needed in their career as a teachers.

\section{Summary of the Findings}

As for conclusion, obviously the findings of this analysis show that the participants in this study were confidently admitted that they were ready to go for their teaching practice after they have gone through most of their courses theoretically and practically; and other relevant exposure explicitly or implicitly in their teacher education program. Socially and psychologically they have the readiness. Besides that they were also well prepared in term of their knowledge and basic skills necessary for the role as a teacher trainee in their teaching practice; and hopefully when they are posted to school as qualified teachers.

\section{DISCUSSION}

The findings from the interviews done in this study were in coherence with the findings from quantitative data analysis of the same study. From the quantitative data analysis; $50.9 \%$ of the total 1,888 respondents scored A grade; $38.6 \%$ scored A- grade; that is $89.5 \%$ or majority of the student teachers score higher grade (Ikhsan \& Norila, 2016). This finding is also in alignment with Furlong (2000) and Norila (2006) who outlined that there was a strong relationship between students' achievement in theoretical part and students' performance in the practical part of their studies in teacher education program.

Shulman in 1987 organized the important domains of knowledge for teachers into seven categories namely content knowledge; pedagogical content knowledge; knowledge of learners; general pedagogical knowledge; knowledge of educational context; curriculum knowledge; and knowledge of educational ends, purposes, and values (Nagendralingan, 2002). Such knowledge was exposed to student teachers in the university where this study was done; and most of the knowledge was mastered by the student teachers at the end of the program. That is why the student teachers were having their confidence to undergo their teaching practice.

Besides that, this finding shows an indication that efforts given to students in their teacher education program in the university where the study was conducted had brought fruit full impact which can be continued further as it exposes student teachers with basic and general knowledge in teaching profession. From here, ideas can also be drawn that readiness towards performing teaching practice can potentially contribute good impact on the performance grade of teaching practice amongst students as well as students' overall achievement and the quality of the graduates.

Other study on other cohorts of students are recommended to be conducted to get clearer picture to be noted and the consistency of the findings. Furthermore, this study was conducted only in a selected teacher training university. Further similar or equivalent studies are still needed such as studies from other teacher training institutions for comparison of the findings. 


\section{ACKNOWLEDGEMENTS}

This study was supported by the Sultan Idris Education University grant given to the author. The authors also would like to acknowledge the contributions of fellow researcher Dr. Norila Md Salleh. Grateful acknowledgement also given to each of the beginning teachers involved in this study and who have kindly contributed with integrity and honesty.

\section{REFERENCES}

Aminah Ayob. (2007). Kajian Keberkesanan Program Latihan Mengajar Universiti Pendidikan Sultan Idris. Sultan Idris Education University Research Grant: 07-20-0001-08/PBU (Not Published).

Boeije, H. (2010). Analysis in Qualitative Research. California: Sage Publication.

Creswell, J. W. (2007). Qualitative Inquiry \& Research Design: Choosing Among Five Approaches. California: Sage Publication.

Eftah Moh @ Abdullah \& Izazol Idris. (2014). Mengenal pasti kefahaman guru berhubung pentaksiran sekolah di daerah Kinta, Perak, Malaysia. In Proceeding6th International Conference on Teacher Education: The Standardardization of Teacher Education - Asian Qualification Framework (pp. 1310-1325). Bandung: Universiti Pendidikan Indonesia.

Furlong, J. (2000). The Role of Higher Education in Initial Teacher Training. London: Kogan Page.

Goh, P.S.C. \& Wong, K.T. (2015). Exploring the Challenges for Teacher Educators. Journal of Research, Policy \& Practice of Teachers \& Teacher Education Vol. 5, No. 1, June 2015, 37-45.

Goh, P.S.C. \& Wong, K.T. (2014). Discerning Beginning Teachers' Conceptions Of Competence Through A Phenomenographic Investigation. Journal of Research, Policy \& Practice of Teachers \& Teacher Education Vol. 4, No. 1, June 2014, 40-47.

Goh, P.S.C, Wong, K.T, Rosma Osman \& Chia Yin Lin. (2012). Discerning Beginning Teachers' Conceptions of Competence Through a Phenomenographic Investigation. Paper presented at the joint AARE/APERA $\begin{array}{lllll}\text { Conference Sydney, 2012.Retrieved January 15, } 2018 \text { from } & \text { 2018 }\end{array}$ https://www.aare.edu.au/data/publications/2012/Goh12.pdf

Ikhsan Othman \& Norila Md Salleh. (2016). Relationship Between Student Teachers' Achievement in Professional Education Courses and Their Achievement in Teaching Practice. Journal of Research, Policy \& Practice of Teachers \& Teacher Education. Vol. 6, No. 2, December 2016, 5-15

Ikhsan Othman \& Norila Md Salleh \& Zaini Abdullah. (2014). Pencapaian Dalam Kursus-kursus Profesional Pendidikan Sebagai Peramal Pencapaian Dalam Program Latihan Mengajar Guru Pelatih. Sultan Idris Education University Research Grant: 2014-0094-106-01 (Not Published).

Melor Md. Yunus, Harwati Hashim, Noriah Mohd Ishak \& Zamri Mahamod. (2010). Understanding TESL Preservice Teachers' Teaching Experiences and Challenges via Post-praticum Reflection Forms. ProcediaSocial and Behavioral Science, Vol.12, 722-728.

Mohammed Sani Hj. Ibrahim \& Zuraidah A. Majid (2002). Masalah profesionalisme guru permulaan di sekolah menengah Wilayah Persekutuan Kuala Lumpur, Dalam Prosiding The Inaugural UPSI International Teacher Education Conference (m.s. 173 - 186). Tanjong Malim : Universiti Pendidikan Sultan Idris.

Mohd Hasani Dali \& Ulaganathan Shanmugam. (2005). The problems and the needs of beginning teachers in Malaysia: A case study. In Proceeding JPPG Education Conference: Education for Sustainable Development (pp. 451-463). Pulau Pinang: Universiti Sains Malaysia.

Nabilah Abdullah \& Nurshamsida Md Shansuddin. (2011). Cabaran dalam pengajaran dan pembelajaran Sains di sekolah menengah harian di Malaysia. Jurnal Penyeldikan Pendidikan, Vol.12, 87-101.

Nagendralingan Ratnadivel. (2002). Reconceptualizing Professional Literacy in Teacher Education: Foundations of Education Reconstructed in Proceedings of Inaugural UPSI International Teacher Education Conference 2002, 358-372.

Norila Md Salleh \& Ikhsan Othman. (2016). Collaboration Between School and Teacher Training Institution in Training Future Teachers. Proceeding International Conference on Language, Education and Civilaization (LECIC) 2016, 106-112.

Norila Md Salleh \& Ikhsan Othman. (2015). Kesediaan Profesionalisme Guru Pelatih Semasa Praktikum. Sultan Idris Education University Research Grant: 2014-0075-107-01 (Not Published).

Sazwani Suhaimi, Noor Shah Saad \& Sazelli Abd Ghani. (2011). Students' perception towards Mathematics teachers' communication behaviour. Journal of Science \& Mathematics Education, 1(1), 59-69.

Zailani Jusoh. (2011). Teaching Teaching practice: A student Teacher's Perspectives. Retrieved January 15, 2017 from www.litu.tu.ac.th/journal/FLLTCP/Proceeding/865.pdf. 